\title{
Node of International Flows or the Other Face of El
}

\section{Eulma}

\author{
Mohamed Gherbi ${ }^{1}$, Badia-Belabed Sahraoui ${ }^{2}$ and Paul Boino ${ }^{3}$ \\ 1. Department of Architecture, Faculty of Science and Technology, University of Tebessa, Tebessa 12002, Algeria \\ 2. Faculty of Architecture, University of Constantine 3, Ali Mendjeli 25016, Algeria \\ 3. Institute of Urbanism of Lyon, University of Lyon 2, Berthelot 69007, France
}

\begin{abstract}
El Eulma has become an important node of transnational informal trade. It maintains strong relationships with international market places since the period where the "Trabendo" have seen a wide development in Algeria. On the national and regional level, the city of El Eulma is the main element of the network of informal merchant areas known by "Doubai" markets. The most important areas are located in the central and eastern of Algeria. This dual membership was conferred to it because of the strong presence of import companies and the existence of discrete and dynamic networks well-organized, formed of false importers. This article focuses on commercial trajectories, the forms of networks and their developments and tries to know the logic. From these trajectories, how the merchant places could be formed in Algeria, as was the case for El Eulma.
\end{abstract}

Key words: Trabendo, international nodes of informal trade, "Doubaï” markets of Algeria, discrete networks of globalization from below, silk road.

\section{Introduction}

The transnational and cross-border informal trade has grown following after the gradual withdrawal of the state and the reduction of its monopoly, especially in the foreign trade sector in favor of private importers. This was made in the framework of the market economy but encouraged by the political instability that had known in Algeria at the time, combined with the unsafe situation after 1990 and the weakness of the state.

This situation has inevitably led to the emergence of informal markets specialized in specific trade segments which the most important were named "Doubaï" markets. They are located in central and eastern Algeria like Algiers (El Hamiz), Setif (El Eulma), Mila (Tadjenanent and Aïn M'lila) and Oum El Bouaghi (Aïn El Fakroun).

The informal market in Algeria was structured

Corresponding author: Mohamed Gherbi, lecturer, research fields: architecture, sustainable urban design, heritage protection, urbanism, informal trade and cities, land use and management of quality in higher education. around the phenomenon known by the "Trabendo". 1 This latter has been apparently imposed as a strength and main pillar of the Algerian economy, and characterized the transitional period from a planned economy to a market economy. Qualified as "underground", 2 clandestine and illegal, the "Trabendo" has become a national expression since 1988, related to the informal in the sense of the "resourcefulness". 3 It was a normal practice in the daily life and well organized, responding to a

${ }^{1}$ The "Trabendo" was born during the economic crisis of the end of 1980s and beginning of 1990s. It is the deformation of the Spanish term "Contrabando" (smuggling), and was borrowed by the retailers of the Algerian western during 1970s and 1980s. The "Haraguas" imported illegal goods from Melia, Tangier via Oujda in Morocco, and passed them through Maghnia in Tlemcen, a border town located in the west of Algeria.

${ }^{2}$ The expression used by Tarrius [1].

${ }^{3}$ The "resourcefulness" is related to the meaning of the temporary work. It includes the all types of trafficking: the resale of imported goods on the street, the real estate market, the medical domain (dental or pharmaceutical), etc. The resourcefulness has infringed the monopoly territory of the state and has started to compete it. It was reinforced by the crisis which had heavily reduced the number of workers in 1997 , that is why many dealers of different ages are versed in the trafficking. 
particular codified system.

The "Trabendo" is organized in fact, almost in the same way as the official economy. It has its own national and international networks of smugglers and information, and its supply markets around the world because the imported goods have multiple origins.

On the other side, the "Trabendo" seems to forge close ties with politicians in the power that significantly affect the economic policy. It has in fact benefited the monopoly in the import, the credits and the banking facilities [2].

In this logic, the migration movements have appeared actively in well-organized networks that partly resemble to those of the official economy. However, they do not benefit any subsidies [2], because most of them are versed in smuggling like the case for cross-border networks [3]. As a real case of these networks, there were the "Haraguas", 4 where most of whom are wealthy but often illiterate, without any level of education [4]. They import of counterfeit goods and/or often with false official statements, and use all allowed and not allowed means to escape the taxation and custom taxes. ${ }^{5}$

The "suitcase trade" or "caba" 6 was the most used tool at the time, before the introduction of import and export authorizations. It was exercised by "Trabendistes" or small importers of "globalization from below", 7 who occasionally or professionally during their travels, visited often various European and Arab countries in the Middle East and the gulf. They used trade roads opened by sailors, students, migrants and pilgrims, and met the traders from the ex-Soviet bloc and from Africa and Asia [10].

\footnotetext{
${ }^{4}$ The "Haraguas" is a term that refers to the smugglers active in the informal. They take advantage of the inadequacy of the administration to override all the legal procedures of the monitoring and verification in the country borders. They are illegal importers or smugglers but different from illegal immigrants who are also part of this category.

${ }^{5}$ It happened, for instance, for an invoice of $€ 10,000$, only the $5 \%$ of its true value is declared, corresponding to the sum of $€ 2,000$.

${ }^{6}$ It is a word of Algerian slang which means the bag or suitcase. ${ }^{7}$ The expression is borrowed from Portes [5], Tarrius [6], Thorez [7] and Pliez [8], [9].
}

The Algerian networks have known a considerable development and dynamism that result from the development of Marseilles' underground activities which their involvement has affected other Mediterranean countries [11].

So following the supply chains in the journey taken by the young Algerian importers of "globalization from below", the relayed spaces emerge from either side of the Mediterranean. They concern cities like Marseille, Naples, Istanbul, Oran, Algiers, Annaba, Tunis, Tripoli, Damascus, etc. Through the informal ways, trade exchanges take place between the two sides. But after the official introduction of the private practice of import-export in Algeria in $1990,{ }^{8}$ the goods start to come from "Dubaî" in the Emirates, and transit Marseille ${ }^{9}$ or the Italian city (Naples) to reach El Eulma for instance. These practices have encouraged the emergence of a wealthy social layer from the year 2000, which was renamed later: the "new multibillionaires" or "s'hab Echkara". 10

\section{The New Wealthy Class in Algeria}

According to the Ministry of Trade in 2004, Algeria had around 40,000 billionaires. But they are passed to 46,000 in 2009 according to the statement and analysis of financial experts [13], with an increase of $13 \%$, dividing them into two categories. The first contains 30,000 billionaires coming from wealthy families who exercise export since colonial times, while the second category includes from 16,000 to 20,000 billionaires constituting nearly $40 \%$ of the informal fund. The estimated index of their total wealth, in the absence of accurate statistics, is situated between 2 and 50 until 60 billion Algerian dinars $(€ 600,000,000) .{ }^{11}$

\footnotetext{
${ }^{8}$ This period was known by the great "Trabendo" or the era of semi-informal import of containers [12].

${ }^{9}$ When the French authorities have tightened controls at ports, particularly Marseille, the imported goods were directed to some Italian port cities.

${ }^{10}$ It is an Algerian term in plural that means the holders of bags full of money.

${ }^{11}$ Ibid.
} 
The origin of the fortune of the second category seems to come from the informal and illegal trade, and contains billionaires who have got rich from the corruption and embezzlement of public funds, where most of them are prosecuted by the courts. However, according to some financial experts, the number of billionaires had reached 50,000 or more during the year 2013. This figure seems far exceed the statistics provided by the NWW (New World Wealth), ${ }^{12}$ in 2012 in the framework of the formal economy. In its recent study, this office confirms that Algeria has 35 billionaires and 4,100 millionaires ${ }^{13}$ in 2012 where the number of dollar millionaires could reach 5,600 in 2020 if the average growth rate remained at $4.1 \%$ [14] of the period of 2012 2020.

The city of El Eulma concentrates a lot of these billionaires where the number of importers has become more of 1,000 , in which most of them are active in the informal markets whereas the huge financial flows that transit this city remain unreported. El Eulma will generate trans-regional flows and be in competition with big cities where some of them have lost their monopoly of supply of markets.

At this scale, El Eulma is considered as the cornerstone of east wholesale markets that surround, by the intensity of trade that has with them. That intensity is based on the couple specialization-monopolization which seems to be well structured, making any distribution of goods throughout the national territory, is obliged to pass through El Eulma.

\section{3. "Doubaï" Markets of the Algerian Eastern}

In the east and the central of Algeria, a dynamic

\footnotetext{
${ }^{12}$ The NWW (New World Wealth) is a consulting cabinet based in Britain that defines the millionaire in his study as an individual with net assets of more than $\$ 1,000,000$ (over 100 million AD (Algerian dinars)). It is based on surveys and data including those provided by transnational institutions like the World Bank and WTO (World Trade Organization).

${ }^{13}$ More than half, nearly 2,300 millionaires counted, are in the capital Algiers. On the other hand, the NWW considers that 4,100 millionaires accumulate a total of $\$ 5,000,000,000$, equivalent to 430 billion $\mathrm{AD}$.
}

network of places, spaces and roads of informal trade of import is formed in the large, medium and small cities. The size of the city in this logic has no importance because the "Doubaii" markets are based on other issues and criteria different from the planning of cities. They have transformed their cities into places of high traffic of goods and accelerated significant changes of their function and urban organization.

From the observations, it appears that the existing "Doubai" markets relay located in the east of Algeria have the role of complementarity with El Eulma by the specialization in one or two commercial segments. They position according to the channels of distribution organized at large scale as major merchant places (Fig. 1). That is why El Eulma is identified as the business segments in particular the hardware, furniture, mobile phones and computers, Tadjenanet, meanwhile, remains active in the import of wood and Ain M'lila in the sale of vehicle parts. For their part, Sidi Mabrouk, which is located in Constantine, and Aïn El Fakroun to Oum El Bouaghi, specialize in cheap clothes, while Bir El Ater in the wilaya of Tebessa is known by the thrift store [15].

The organization at this scale has permitted the maintaining of exchanges between these poles as long as possible, but the massive and continuous arrival of imported goods or those locally produced, to El Eulma and the speed of distribution to the four corners of the country and the neighboring countries such as Tunisia, testify the importance and how El Eulma takes its place in the region.

\section{Global Discrete Networks in El Eulma and Their Strategies}

The geography of transnational trade road which was drawn before 1990 connected in fact, El Eulma to Egyptian cities by the illegal import of the stationery, hardware and furniture, especially from 1988 to 1990. El Eulma was also linked to Libyan cities, particularly Tripoli by informal import of mobile phones, cigarettes 


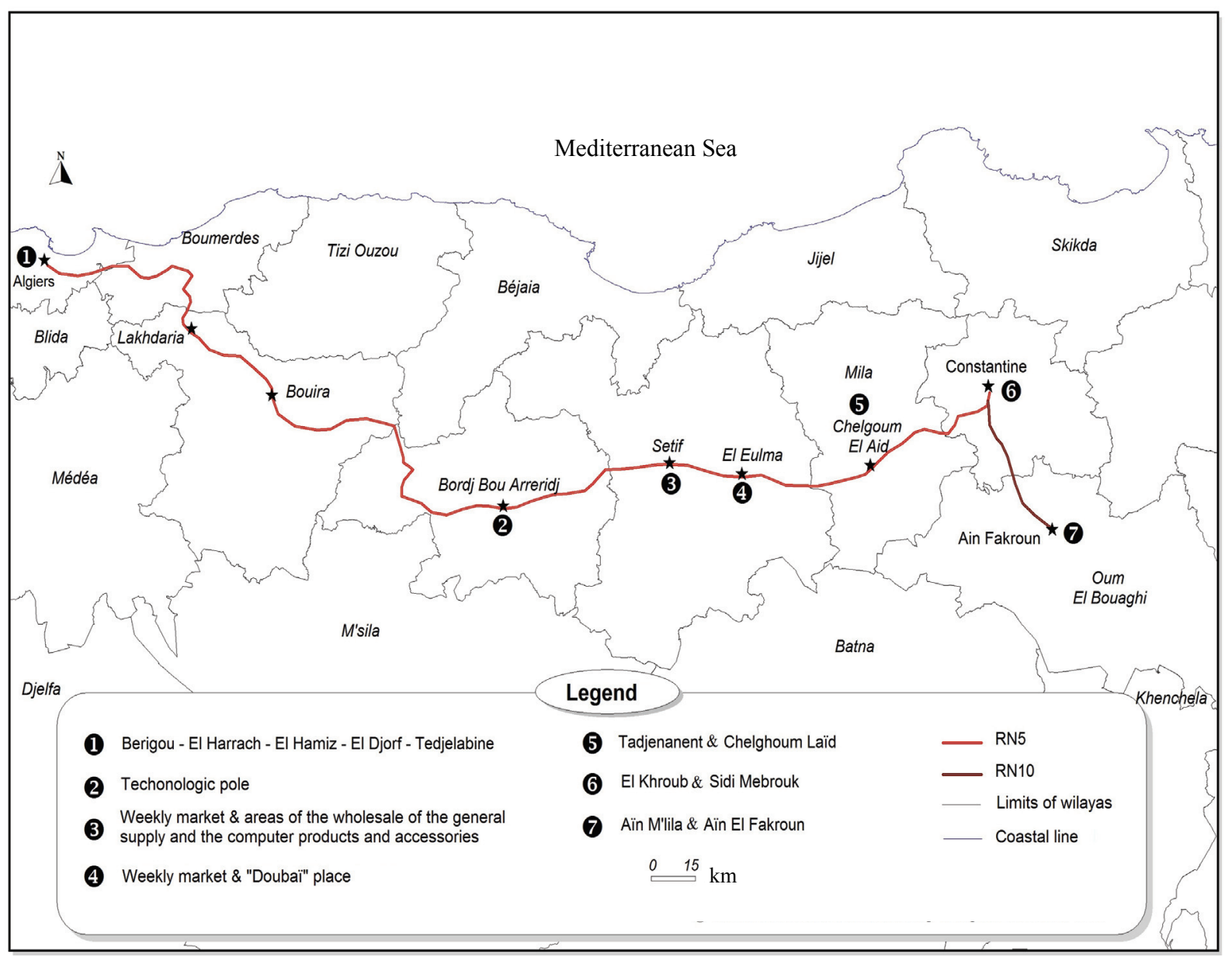

Fig. 1 Markets of national and regional importance near of the RN5 (national road).

Source: Gherbi, M. 2011. Tourism's base map of Algeria, INCT (National Institute of Cartography and Remote Sensing), 1997 ed.

and clothing, especially jeans. The transfer of goods was affected via the terrestrial borders in the east of the country, ${ }^{14}$ by the traders and/or smugglers of Tebessa and Sufis, playing the role of intermediate smugglers. ${ }^{15}$

The products arrived in El Eulma, came generally from important places, known for their low prices and the mass and variety of products, such as Selloum in the Egyptian-Libyan border and the markets of the capital Tripolis and those of Ben Gardane located in the Tunisian-Libyan border $[7,9,16]$.

\footnotetext{
${ }^{14}$ The Algerian-Libyan borders but also via Tunisia.

${ }^{15}$ It should be recalled that Algerian smugglers use the land border axis in the east of Algeria, formed by El Taref, Souk Ahras, Tebessa and Oued Souf, in cooperation with their Tunisian and Libyan similars. They take the uncontrolled paths and trails by the security authorities of the three countries to pass the goods.
}

A discreet organization has thus grafted in the territory of each country. ${ }^{16}$ This discontinuous spacial device arrives to form a dynamic link that ensures the illegal distribution to other countries in the south such as ex-Sudan, Mali and Niger. The smugglers and dealers store their goods in hidden warehouses and expect the easing of control procedures applied at the borders, to move them.

Once the export-import has become authorized to the private investor by granting him the commercial register, some "Mâalims" $" 17$ of El Eulma specialized

\footnotetext{
${ }^{16}$ Pliez and Boubakri have identified and analyzed the roads of transit of goods used in the smuggling into the territory of Libya and Tunisia, which all lead to the east border of Algeria. It is a real sieve where El Eulma is well ingrained in these roads [15].

${ }^{17}$ It is an Algerian term in plural which means the big bosses or the notables of the city.
} 
in the sale of furniture, for instance, have realized that Egypt was only the interface of the re-export of such goods, and that Indonesia is the place of origin of manufacture. They have since the beginning of 1993, taken the new commercial circuit leading to the cities of this country, looking for contacts with producers and for the acquisition of exclusive rights to certain brands, at the lowest possible price. And since then, the containers full of furniture arrive to the ports of Algiers and then are moving towards El Eulma with often false statements and without invoices.

Parallel to this network, another network was formed between El Eulma and some cities of Turkey and especially Istanbul during 1995 1996, where a large informal trading was recorded for multiple trades which confirm the traders met in the investigations carried out in "Doubaî" place of El Eulma.

The strategy of this network, because of the lack of political visibility of the state at this period for import and export, consisted in that two traders travel both for a group of traders who work with them and trust them. These dealers were selected on the basis of their knowledge in Turkey and their experience in the workings and circuitry of the informal import. They have an average financial capital formed from their own fund and the fund of their colleagues (cash money). ${ }^{18}$

Once in Turkey, these both traders will quickly find privileged interlocutors from whom they will pass their commands, but after having done a rapid check of goods prices in the market. They negotiate prices and buy variety of product batches other than the hardware (fabrics, household appliances, batteries, shoes, etc.) to put them in containers to be transported by the sea road.

The private forwarders, usually the Kurds, register the goods and ship them. They have a better knowledge of the Arabic language, which permit them

\footnotetext{
${ }^{18}$ The financial assistance from the state to traders was not operational because the procedures were not applied because of the economic and security situation of the country.
}

to deal with customers, mostly from the Middle East countries such as the Syrians and also the traders of Maghreb, especially the Algerians and Tunisians.

In the beginning of the official exercise of import to El Eulma and in the atmosphere devoid of confidence, the traders and importers avoided taking the risks and invested in the import only with modest capital. In that way, if the goods, for a reason as for another, is destroyed during their shipment or seized by customs or police suddenly uncooperative during checks, which from time to time become hard, the costs of this loss will be shared between all merchants concerned by this delivery.

Once out of the ports of Algiers, the trucks and trailers carry the containers via the RN5 (national road) and cross all the roadblocks deployed by the national gendarmerie and customs, or the services of the national security at the entrances and exits of the cities. ${ }^{19}$ Just arrived at El Eulma, the traders start to share and store the goods in their warehouses. Some merchants sell their products with lower prices and entrust much of the goods to a network of resellers who distribute it to the four corners of the country. This method facilitates them to repay all their stay expenses in Turkey, and recover quickly their profits.

The technic of purchase of diversified products was adopted by importers traders of El Eulma even in the imports of "Dubai" in the Emirates, considering the possible arrival on the market, of similar products in large quantities. Also the import of a single type of goods may risk making too slow the rotation of their stock because of the particularity of the Algerian market.

\subsection{Direction to "Dubaï" in the Emirates}

The pace of the development of commercial

\footnotetext{
${ }^{19}$ The shipments arriving at the names of some traders and importers undergo, from their entry into ports until their final delivery to El Eulma, a minimum of control. In some cases, they are exempt from all types of controls and checks because of their owners whom have relationships with certain of high officials of the Algerian state.
} 
networks in El Eulma has experienced a fast pace since the end of 1996 and beginning of 1997, due to the practice of the merchant road to "Dubaï" in the Emirates as a new destination of supply for their imports. This road begins seriously to compete the road to Istanbul in Turkey for three following reasons:

(1) The goods off food, ordered and imported to El Eulma were not all made in Turkey;

(2) Most of goods come from "Dubaï";

(3) The Turkish forwarders were just intermediates because they concluded with the Iranian forwarders installed in "Dubaï" in the Emirates, the transit terms and reshipment of the commands of their Algerian customers, especially the Eulmis.

The road to "Dubaï" in Emirates has allowed the traders of El Eulma to make profits and savings in time and money. At first, orders of the first import companies in El Eulma ${ }^{20}$ were treated by the Iranian forwarders. $^{21}$ However, the multiplicity of flows of goods due to the transactions between El Eulma and "Dubaï" has been accompanied by the opening of companies of cargo transits by the Eulmis installed in "Dubaï" that will process all orders to El Eulma.

This change will give to El Eulma, a strong reputation and a new identity and will transform its "Doubaï" district to a powerful merchant place. It was founded by these importers-traders based in El Eulma, exceeding 1,000 importers.

The orientation towards "Dubaï" in the Emirates is dictated by several factors. The most important are the absence of border controls, the strong flexibility in the administrative procedures and the considerable reduction of the customs duty to $4 \%$ of the value reported [17]. These new conditions have rendered the

\footnotetext{
${ }^{20}$ In theory, the trade registers established in order to benefit several advantages, as the exemption and reductions of taxes are related to the activity of import-export. However, only few of the beneficiaries really exercise the import-export, because in most of the cases observed, their activity is only limited to the import.

${ }^{21}$ According to the interviewed merchants, the fees of services of some Iranian forwarders who have rich knowledge of the mechanisms of workings of administrative procedures in Emirates are very competitive.
}

traders using fraudulent introduction of most products from "Dubaï", and have made that the selling price of a product imported to El Eulma, equal to two or three times cheaper than the local product or the national sold. For instance, a midsize refrigerator of two doors with a freezer, imported in 2011 was sold to 20,000 Algerian dinars per unit (retail price), which is near of $€ 150,{ }^{22}$ whereas that produced in Algeria, cost 33,000 $\mathrm{AD}$ equivalent to $€ 250$. In this case, the imported product permits to the Algerian customer to save $13,000 \mathrm{AD}(€ 100) .^{23}$

\subsection{Reinvention of the Silk Road}

After several trips to "Doubai" in the Emirates, the merchants and traders of Eulmis have realized that "Doubaï", is in fact only a center for the global transit of goods flow re-exported from the Southeast Asia: South Korea, Malaysia ${ }^{24}$ and China. They have discovered that $95 \%$ of the goods entering to El Eulma routed from the ports of "Hong Kong" 25 via "Doubaï", and are manufactured in a small Chinese town located at $300 \mathrm{~km}$ to the east- "Yiwu", classified as one of the greatest Chinese centers of the hardware [19] which is also the most present in El Eulma.

When China was closed to the world, the merchants of "Dubaï" in the Emirates passed their commands of the products from the Chinese manufacturers and resold them to the countries of the world. But since the GDP (gross domestic product) ${ }^{26}$ of China has

\footnotetext{
${ }^{22}$ According to the rate applied in the parallel market of currency. The currency exchange has known an exponential growth compared to the value of the Algerian dinar. The proof is that, use 2008 2011 as an example, Euro was worth $133 \mathrm{AD}$ (Algerian dinars) but in 2014, it increased to $156 \mathrm{AD}$ and is arrived to more of $160 \mathrm{AD}$. It should be recalled that Algerian dinars has lost $20 \%$ of its value according to the statement of the governor of the Central Bank of Algeria presented to the National People's Congress and the Senate.

${ }^{23}$ The results of surveys conducted in 2006 2011.

${ }^{24}$ The furniture is imported from Malaysia.

${ }^{25}$ It contains the third biggest port in the world where tens of thousands of containers depart from this port [18].

${ }^{26}$ In 2010 , the gross domestic product of China, in a nominal term, has amounted to $\$ 5.8786$ trillion compared to $\$ 5.4742$ trillion for Japan, but the GDP/inhabit., stays 10 times lower in China than in Japan [20].
} 


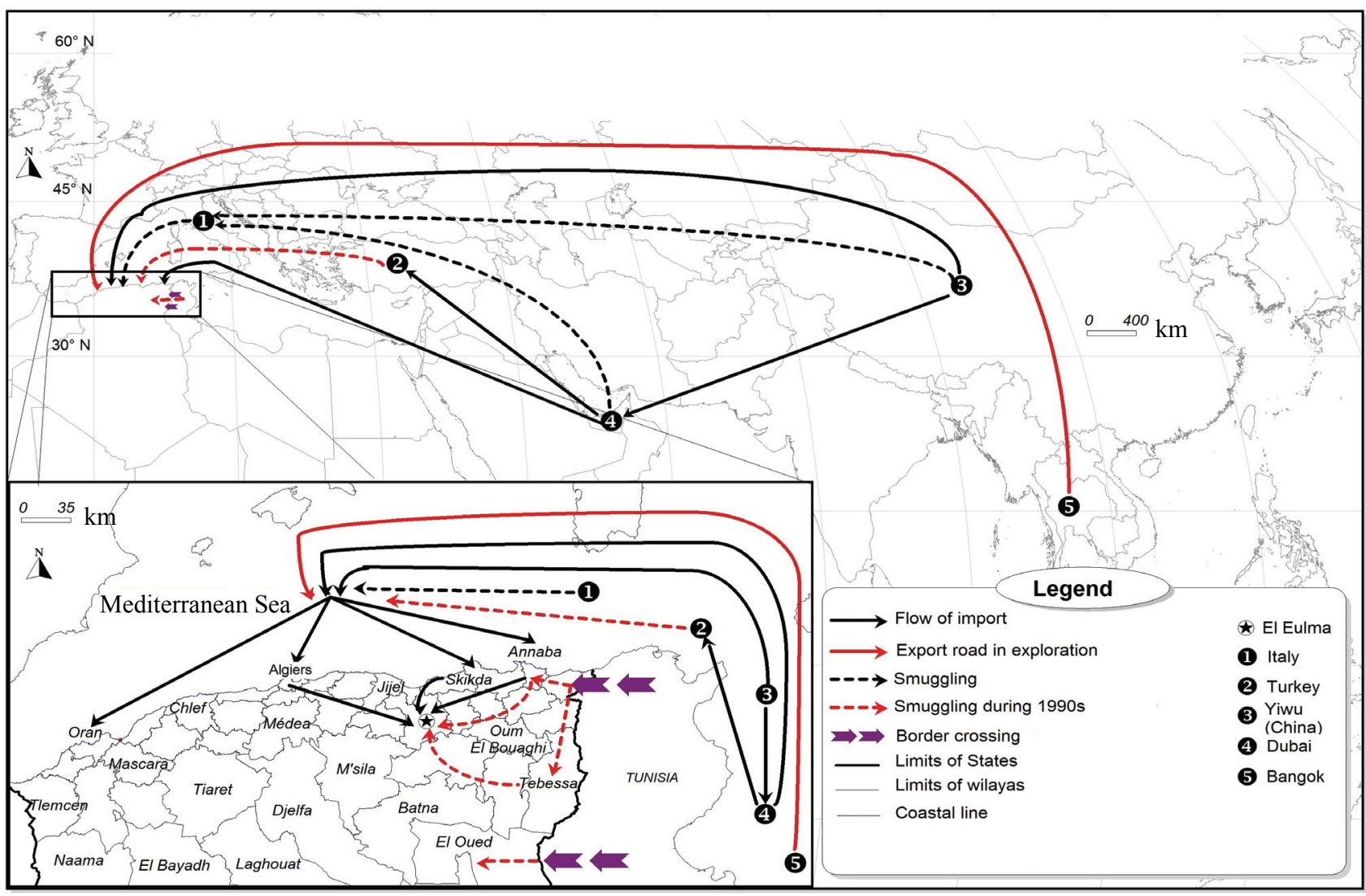

Fig. 2 Merchant places and new roads undertaken by the Eulmis importers.

Source: Gherbi, M. 2010. Based on world map and map of administrative of Algeria, 1984.

increased significantly and a mass of multinationals have installed after its opening to the world, China has known a development in all sectors of the economy never seen before, due to the abundance of the skilled but cheaper workforce.

China exports today the majority of its production to all five continents. It was ranked as the second powerful economy in the world in 2010 behind the United States of America. The place was occupied by Japan since 1968. An evolution promises the throne of China in 2025 according to the estimates by the World Bank and various financial institutions, ${ }^{27}$ with the possibility of marginalization of Europe in 2020, if the rate of its current growth is maintained over a decade as advocated by some strategists [21].

It was obvious therefore that the traders-importers of El Eulma fly to that country and specifically to

\footnotetext{
${ }^{27}$ Ibid.
}

Yiwu in the end of 1990s. ${ }^{28}$

Having the names of some suppliers and the address of the Arab district ${ }^{29}$ for their stay, ${ }^{30}$ they visit alone or in small groups to Yiwu during the periods of universal exhibitions, ${ }^{31}$ and conclude their business at the lower cost and without intermediates.

\footnotetext{
${ }^{28}$ They are less interested in the important Chinese cities like Beijing or Shanghai, but they know Yiwu and the "exotic" district well, concentrating the Arab and Muslim communities. ${ }^{29}$ This district is appeared in Binwang, near the first exhibition center, in the end of 1990s. It is known for the trade with the Arab and Muslim countries but currently, it is closed for urban renovation. It has taken the name "Exotic Street" in reference to the name of its main street. Morphologically, the district is formed of several islands and five parallel streets, lined with shops. It is cosmopolitan due to the presence of Uighurs, Huis, Kazakhs, Arabs, Africans and Turks. This district contains restaurants and one of them is managed by one Eulmi who takes care of the passing Algerians traders [22].

${ }^{30}$ The restaurant of this Eulmi was closed because of the urban renewal in the district suffered, therefore the Algerians who come, are often found in the snack and in the two Chinese hotels, located near the "Exotic street" [22].

${ }^{31}$ Yiwu organizes every year about 83 universal exhibitions.
} 
At Yiwu, they walk with local translators, often young Chinese women to finish their orders on site. ${ }^{32}$

Many foreigners living in Yiwu, opened their representations as traders. They organize the delivery of orders to their country of origin. Approximately twenty offices belonging to the Algerians exist in the Arab district. They treat large orders towards Algeria and recruit local workforces and those coming from Algeria.

The presence of the Algerian community starts to become visible in the city and is now in competition with the Egyptian, Syrian, Lebanese and Turkish communities [22]. For the Eulmis importers and at present, they are exploring new trade routes bringing them to far places such as Bangkok in Thailand, Indonesia and India, looking for goods with lower prices than proposed by their traditional suppliers (Fig. 2).

\section{Conclusions}

The experience acquired over these years and the relationships with wholesalers or the forwarders of the scapegoat composed of Marseille, Naples, Istanbul and "Dubaï", have opened a door to the importers-traders of El Eulma. The possibilities of investment allow the traders to conquer the new international trade places grafted on the old roads in the countries of the Southeast Asian, especially China. These importers are working for broadening their relationships and increasing their sites of supply without going through the intermediates.

By following the roads undertaken by the importers of El Eula, the figure of the discontinuous commercial discrete networks is reconstituted and the actors that animate are identified. This pattern has shown its success in its adaptation and its organization inside the country and has crossed the national borders and the boundaries of the international agreements. It has permitted to better taken of the trajectories and forms

\footnotetext{
${ }^{32}$ They command lower quality products because of the weak purchasing power in Algeria.
}

of structuring networks and to better understand the logic of how, from these roads, could be formed in Algeria the merchant places like the case of El Eulma, with national radiation and international connections.

\section{References}

[1] Tarrius, A., and Missaoui, L. 1995. Arabs of France in the World Economy from Below. Avignon: Monde en Cours Collection, 220.

[2] Battegay, A. 2005. "Dubaï: the Trading Economy and Migratory Crossroad. Study of Functioning." In Worlds in Movements, Migrants and Migration to the Middle East at Nearby of XXI Century, edited by Jaber, H., and Metral, F. Karthala: French Institute of the Near East, Direction of Contemporary Studies DGCID (MAE)-CNRS (FRE 2895).

[3] Peraldi, M. 2001. Cabas and Containers. Informal Trading Activities and Cross-border Migrants' Networks. Paris: Maisonneuve \& Larose, 361.

[4] Boumaza, Z. 2003. "Trabendo, a Mode of Informality in Algeria of Years 1980 1990.” In Transversal Modernities: Citizenship, Politic and Religions, edited by Kouvouama, A., and Germod, C. D. Brazaville: Paari Editions, 107-11.

[5] Portes, A. 1999. "Globalization from Below, Emergence of Transnational Communities." In Proceeding of Social Science Research, 15-25.

[6] Tarrius, A. 2002. Globalization from Below: New Nomads of the Underground Economy. Le Muveran: Voix \& Regards Collection, 169.

[7] Thorez, J. 2008. "Bazaars and Trade Roads to Central Asia-Post-soviet Transformation and Globalization from Below." Revue Européenne des Migrations Internationales 3 (24): 167-89.

[8] Pliez, O. 2007. "The Chinese Jeans in the Streets of Cairo, or the Discrete Spaces of Globalization." M@ppemonde 88. Accessed February 19, 2008. http://mappemonde.mgm.fr/num16/articles/art07404.html.

[9] Pliez, O. 2010. "The Silk Roads Lead to Yiwu (China). Contractors and Muslim Migrants in a Chinese Economic Area." L'Espace Géographique 2 (39): 132-45. Accessed June 20, 2011. http://www.cairn.info/revue-espacegeographique-2010-2-p-132.htm.

[10] Battegay, A. 2000. "Dubaï, the New Merchant Place." Presented at the 2000 Seminar of the Mediterranean Sociology Laboratory, Aix-en-Provence, France.

[11] Marchal, R., Adelkhah, F., and Hanafi, S. 2001. Dubai, the Global City. Paris: National Center for Scientific Research, 131.

[12] Cote, M. 2001. "New Territorialities in Algeria." In Where Is Going Algeria?, edited by Mahiou, A., and 
Henry, J. R. Paris: Iremam Editions, 257-72.

[13] Bachouche, N., and Benyehia, H. 2009. " 46,000 Billionaires in Algeria." Echorouk 08/05. Echorouk. Accessed July 19, 2010. http://www.echoroukonline.com/f ra/index.php?news $=4754$.

[14] Grim, N. 2013. "According to a Study of New World Wealth, in 2012, Algeria Had 35 Billionaires and 4,100 Millionaires in Dollar.” El Watan, 09/03. Accessed October 18, 2013. http://www.elwatan.com/pdf/telecharg er2.php?pdfpf=/archives/edition.php\&pdfg=\%2Fpdf $\% 2 \mathrm{Ft}$ elecharger.php\%3Fdir\%3DJOURNAL\%26file\%3D2013 0903.pdf\&ed=2013-09-03.

[15] Gherbi, M. 2010. "Doubaï in El Eulma, from a Residential District to an Important Place of Trading." In Transversal Days, Organized by LISST (Interdisciplinary Laboratory Solidarities, Societies, Territories) (Cas-Cers-Cieu). Toulouse: Le Mirail University.

[16] Boubakri, H. and Mbarek, W. 2009. "Places, Actors and Networks of the Informal Economy at the Tunisian-Libyan Border." In Rural Development, Environment and Territorial Interests: Cross Views Moroccan Oriental and Tunisian South-Eastern, edited by Bonte, P., Elloumi, M., Guillaume, H., and Mahdi, M. Tunis: Cérès Editions, 343-62.

[17] Lavergne, M. 2002. "Dubai or Incomplete Metropolization, a Relay Pole of the Economy of the
World." Les cahiers de la Méditerranée 64: 257-96.

[18] Dusci, S. 2009. "The Exclusive Survey: The New Mercenaries of the Anti-counterfeiting Fight." In Emission Broadcasted. French TV Channel M6, September 27. Accessed October 10, 2009. http://www.m6replay.fr/\#/info/enquete-exclusive/ 2530.

[19] Jianguo, S. 2005. "Made in Taiwan. The Chinese Goods in Algeria." Xinhua News Agency. Accessed March 9, 2006. http://www.french.xinhuanet.com/french/2005-06/2 9/content_133081.htm.

[20] Le Monde.fr. 2011. "China Has Become the Second World Economy.” Le Monde.fr. Accessed May 5, 2011. http://www.lemonde.fr/economie/article/2011/02/14/la-ch ine-est-devenue-la-deuxieme-economie-mondiale_147 9580_3234.html\#xtor=AL-32280184.

[21] Mebtoul, A. 2012. "Which Prospects for the Algerian-Chinese Cooperation?" Liberté, 07/11. Accessed December 14, 2012. http://www.liberte-algerie. com/6146.pdf.

[22] Belguidoum, S. 2014. "The Dynamism of New Merchant Places of the Algerian Eastern: An Urban Reconfiguration and New Social Data." HAL-SHS (Sciences de l'Homme et de la Société). Accessed March 4, 2014. https://halshs.archives-ouvertes.fr/halshs-009364 44. 